\title{
Eksplorasi Nilai-nilai Kesetaraan dalam Pendidikan Pesantren Mu’ādalah
}

\section{Mufiqur Rahman ${ }^{\text {a), }}$ Maskuri Bakri ${ }^{\text {b), }}$ Hasan Busri c), Zainullah d), Roro Kurnia Novita Rahmawati e)}

a) Institut Agama Islam Al-Khairat Pamekasan, http://orcid.org/0000-0002-5098-5173

b) Universitas Islam Malang,

c) Universitas Islam Malang,

c) Universitas Islam Malang,

d) Institut Agama Islam Al-Khairat Pamekasan,

\section{ABSTRAK}

Salah satu nilai moderasi Islam adalah kesetaraan. Kesetaraan dalam pendidikan menjadi sangat penting untuk memastikan proses pendidikan yang berkeadilan (equity) dan berkesetaraan (equality). Pesantren Mu'ādalah adalah satuan pendidikan yang ekslusif, dengan sistem pendidikan yang otonom, mandiri dan berbeda baik dengan sekolah, madrasah atau pesantren lainnya. Penelitian ini bertujuan untuk mengeksplorasi nilai dan praktik kesetaraan dalam pendidikan Pesantren Mu'ādalah secara inklusif. Dengan pendekatan penelitian etnografi, Pesantren Al-Amien Prenduan Sumenep dipilih sebagai lokus penelitian. Penelitian ini menemukan bahwa, Pesantren Al-Amien tidak hanya menjadi Pesantren Mu'ādalah yang setara secara institusional, tetapi juga memiliki substansi dan praktis kesetaraan itu sendiri. Nilainilai spiritual, integrasi keislaman dan keindonesiaan, dan implementasi budaya lokal pesantren dalam praktik kelembagaan memberikan justifikasi esensi kesetaraan pesantren mu'ādalah dengan lembaga pendidikan lainnya.

\section{ABSTRACT}

One of the values of Islamic moderation is equality. Equality in education is very important to ensure a just education process (equity) and equality. The Mu'ādalah pesantren is an exclusive educational unit, with an education system that is autonomous, independent and different from schools, madrasahs or other types of pesantren. This study aims to explore the values and practices of equality in Mu'ādalah pesantren inclusively. With an ethnographic research, Pesantren Al-Amien Prenduan Sumenep was chosen as the research locus. This research found that, Al-Amien pesantren is not only an institutionally equal Mu'ādalah Islamic Boarding School, but also has substance and practical equality itself. Spiritual values, integration of Islam and Indonesianness, and the implementation of local pesantren culture in institutional practices justify the essence of the equality of mu'aldalah pesantren vis-a-vis other educational institutions.

\section{KATA KUNCI}

Kesetaraan; Pesantren education; Pesantren Mu'ādalah.

\section{KEYWORDS}

Equality; Pesantren Education; Pesantren Mu'ādalah. 
Mufiqur Rahman, et. al.

\section{A. Pendahuluan}

Pesantren sebagai subkultur ${ }^{1}$ dalam segala aspek kehidupan di dalamnya baik secara nilai dan prinsip sampai pada sistem pendidikan yang dianutnya begitu distingtif. Sehingga Pesantren disebut sebagai warisan bentuk pendidikan asli Indonesia. ${ }^{2}$ Pesantren menjadi sistem pendidikan yang digunakan sejak masa kerajaan Nusantara, seperti kerajaan Demak di Jawa dan kerajaan Islam Pasai di Aceh. ${ }^{3}$ Azyumardi Azra menyebut pesantren sebagai pusat pendidikan Islam ${ }^{4}$ yang menjadi simbol peradaban Islam Nusantara. Dalam sejarahnya, pesantren selalu progresif dan bergerak maju. Dulu pesantren hanya terdapat di Jawa. Namun saat ini pesantren tumbuh pesat di Sumatra, Kalimantan, Sulawesi dan daerah lain di Indonesia. Pesantren juga tidak hanya berperan sebagai pusat studi Islam, tapi juga menjadi pusat perubahan sosial. Pesantren kini telah adaptatif dengan beragam kurikulum, mulai dari pendidikan dasar hingga jenjang perguruan tinggi. Bahkan pesantren juga melakukan pemberdayaan ekonomi dan teknologi. ${ }^{5}$

Di tengah pesantren yang adaptatif dengan perkembangan zaman, ada beberapa pesantren dengan varian modelnya atau sistem pendidikannya yang mengacu kepada kurikulum nasional. Ada pula pesantren yang bertahan dengan corak sistem pendidikannya yang asli, yaitu menjadikan kitab kuning sebagai kurikulum utamanya. Tipologi pesantren seperti ini berdiri di atas local culturenya dan tidak dapat "dipaksakan" agar sama dengan pesantren lainnya. Itu sebabnya pemerintah menerbitkan Peraturan Menteri Agama no. 18 tahun 2014 tentang satuan pendidikan mu'ādalah yang memberikan legalitas pesantren untuk dapat bertahan dengan "keasliannya". Peraturan tersebut juga menetapkan pesantren sebagai lembaga pendidikan yang setara dengan pendidikan formal. ${ }^{6}$

Salah satu keunikan pesantren mu'ādalah adalah mendapatkan kepercayaan dari pemerintah untuk membuat sistem pendidikan, kurikulum, dan kelulusan santri secara mandiri. Bahkan ijazah diberikan sendiri oleh pesantren tanpa mengikuti Ujian Nasional yang diselenggarakan oleh pemerintah. Intinya, lembaga pesantren setelah mendapatkan SK mu'ādalah secara de facto dapat mendisain pendidikan pesantrennya secara mandiri yang selaras dengan kearifan lokal pesantren. Maka di antara pesantren mu'ādalah tidak dapat diseragamkan, sebab di dalam pesantren $m u$ 'ādalah sendiri terdapat model, sistem dan budaya pesantren yang berbeda satu sama lain. Ada yang mengusung konsep kulliyah al mu’allimił̀ al-Islāmiyah, ada juga yang tarbiyah al-muallimì̀ al-

\footnotetext{
${ }^{1}$ Abdurrahman Wahid, Pesantren sebagai subkultur, dalam M. Dawam Raharjo (Ed) Pesantren dan Pembaharuan (Jakarta: LP3ES, 1974), 43.

${ }^{2}$ Nurcholis Madjid, Bilik-bilik Pesantren (Jakarta: Dian Rakyat, 2010), 3.

${ }^{3}$ Moh. Hamzah, "Tranformasi Pondok Pesantren Mu'adalah: antara Fakta Historis dan Tantangan Masa Depan" (Jurnal Reflektika Volume 13, no 1 Januari-Juni 2018), 25.

${ }^{4}$ Azyumardi Azra, Islam in Southeast Asia: Tolerance and Radicalism, (Melbourne: The University of Melbourne,2005), 5.

${ }^{5}$ Azyumardi Azra, Islam in Southeast Asia, 5.

${ }^{6}$ Baca Peraturan Menteri Agama Republik Indonesia Nomor 18 tahun 2014 tentang satuan pendidikan muadalah pada pondok pesantren
} 
islāmiyah, kemudian juga ada yang memakai konsep dirasah mu’allimì̀ al-Islāmiyah. Kemudian jenjang pendidikannya berbeda dalam proses kelulusannya; ada yang 6 tahun, ada pula yang 4 tahun. ${ }^{7}$

Otonomi pendidikan yang diberikan pemerintah kepada pesantren mu'ādalah untuk melaksanakan bentuk pendidikan sesuai dengan local wisdom masing-masing pesantren melahirkan sebuah perhatian tersediri bagi penulis. Di sisi lain, praksis dan nilai kesetaraan yang ada pada pesantren mu'ādalah juga menarik untuk dieksplorasi. Oleh sebab itu, penelitian ini akan mengupaskanya melalui pendekatan kualitatif. Melalui pendekatan tersebut, penulis akan mendiskripkan dan menganalisis sebuah fenomena, peristiwa aktivitas sosial, sikap kepercayaan, persepsi, pemikiran orang secara individual maupun kelompok. ${ }^{8}$ Dengan demikian, penulis berusaha memahami sebuah fenomena dan peristiwa dalam proses pembelajaran pendidikan kesetaraan baik dalam aspek sosiologis, budaya, ekonomi dan pedagogis yang diterapkan dalam pola pendidikan di pesantren mu'ādalah. Penelitian ini menggunakan analisis data etnografi dengan siklus analisis data model Spredly, yaitu analisis domain (grand tour), pengamatan terfokus (mini tour), analisis taksonomi, pengamatan terlibat, dan analisis kompenensial, serta analisis kultural atau tema budaya. ${ }^{9}$

Dengan beberapa mini tour yang peneliti lakukan ini, semakin dalam melakukan observasi dan wawancara maka semakin banyaklah data etik maupun emik yang menunjukkan realitas nilai kesetaraan dalam pendidikan pesantren mu'ādalah. Maka, hasil dari mini tour ini telah mempengaruhi penulis untuk menjadikan pesantren mu'ādalah sebagai lokus penelitian. Penulis membingkai penelitian ini dengan judul: Eskplorasi Nilai-nilai Kesetaraan dalam Pendidikan Pesantren Mu'ādalah. (Studi etnografi di Tarbiyat al-Muallimien Al-Islamiyah (TMI) Pesantren Al-Amien Prenduan Sumenep). Dengan mempertimbangkan konteks penelitian di atas, maka penelitian ini secara khusus telah menjawab permasalahan utama secara deskriptif dan interpretatif bagaimana praktik nilai-nilai kesetaraan dalam pendidikan pesantren mu'ādalah.

\section{B. Pendekatan Nilai Spiritual}

Pendidikan Islam merupakan upaya pembentukan manusia melalui proses perubahan sikap dan tingkah laku yang sesuai dengan petunjuk agama Islam. ${ }^{10}$ Senada dengan ini, Hasan Langgulung memberikan konsepsi tentang pendidikan Islam sebagai proses spiritual, akhlak, intelektual, nilai-nilai, prinsip dan teladan, ideal dalam dunia dan akhirat. ${ }^{11}$ Kemudian Ahmad D. Marimba, mengatakan bahwa pendidikan Islam adalah bimbingan jasmani dan ruhani menuju terbentuknya kepribadian utama menurut ukuran-ukuran Islam. ${ }^{12}$

\footnotetext{
${ }^{7}$ Baca Peraturan Menteri Agama Republik Indonesia Nomor 18 tahun 2014 tentang satuan pendidikan muadalah pada pondok pesantren

${ }^{8}$ Nana Syaudih Sukmadinata, Metodologi Penelitian Pendidikan (Bandung : Remaja Rosdakarya, 2006), 60.

${ }^{9}$ Spradley, Jame P, Participant Observation (Newyork: Holt, Rinehalt and Winston, 1980), 180.

${ }^{10}$ Zakiah Daradjad, IImu Pendidikan Islam (Jakarta: Bumi Aksara, 1992), 25.

${ }^{11}$ Hasan Langgulung, Manusia dan Pendidikan (Jakarta: Al-Husna Zikro, 1992), 62.

${ }^{12}$ Ahmad D. Marimba, Pengantar Filsafat Pendidikan Islam (Bandung: Almaarif 1962), 23.
} 
Mufiqur Rahman, et. al.

Pandangan Pakar Pendidikan Islam di atas menunjukkan bahwa Pendidikan Islam tidak dapat dipisahkan dari proses spiritual. Maka nilai budaya kesetaraan dalam budaya kehidupan pesantren tidak dapat dipisahkan dari adanya proses spiritual bahwa ruh atau jiwa pesantren yang menyatukan spirit kesetaraan. Mengenai ruh dan akal masing-masing mengandung pengertian fisik-biologis, mentalpsikologis, dan spiritual-religius. Ruh dalam kajian Imam al-Ghazali memiliki dua makna, pertama, sebuah jenis (benda yang sangat halus yang bersemayam dalam rongga hati jasmani. Kemudian ruh itu bertebaran ke seluruh tubuh, menimbulkan cahaya kehidupan, menumbuhkan perasaan, melahirkan pendengaran, penglihatan dan penciuman. la ibarat cahaya sebuah lentera yang memancar, menembus ke seluruh penjuru bagian-bagian rumah. ${ }^{13}$

Ruh atau jiwa pesantren yang menyatukan sprit kesetaraan adalah di pesantren Al-Amien Prenduan adalah Pancajiwa yaitu jiwa keikhlasan, jiwa kesederhanaan, jiwa kesanggupan menolong diri sendiri berdikari berdiri di atas kaki sendiri, jiwa ukhuwah islamiyah yang demoktratis antar santri dan jiwa bebas. ${ }^{14}$

Seluruh santri harus menanamkan sikap dan rasa ikhlas sebagai jiwa/ruhnya dalam menjalankan proses pendidikan di pesantren semata-mata untuk beribadah kepada Allah, sehingga dengan keikhlasan semua santri diharapkan menyadari arti "lillah" dan ketaqwaan. Kemudian, seluruh santri harus memiliki ruh kesederhanaan yang bermakna agung bukan berarti "nerimo" kemiskinan atau kemelaratan, tetapi mengandung unsur kekuatan dan ketabahan hati. Dari ruh ini akan terpancar jiwa besar berani maju dalam kehidupan. ${ }^{15}$ Seluruh santri mampu hidup bersama dengan semangat gotong royong. ${ }^{16}$ Pada saat yang sama, santri harus berjiwa ukhuwwah islamiyah, di mana dalam 24 jam kehidupan santri di pesantren berjalan dengan suasana persaudaraan dan kasih sayang. Terakhir, berjiwa bebas, di mana santri seluruhnya bebas menentukan masa depannya dan hidupnya di masyarakat. ${ }^{17}$

Inilah proses penanaman jiwa di pesantren mu'ādalah, dalam konteks psikologi, Jhon W. Satrock, menyatakan ada empat proses pendidikan yaitu pemberdayaan siswa, pengajaran budaya yang relevan, pendidikan berpusat pada persoalan, meningkatkan hubungan di antara anak dari berbagai kelompok etnis. ${ }^{18}$ Salah satu proses psikologi dalam pendidikan adalah pemberdayaan siswa. Maka ada satu pola proses yang tidak sebutkan oleh Lickona, namun ternyata menjadi dorongan pemberdayaan yang sangat kuat terhadapat jiwa kesetaraan santri di kedua pesantren ini. Yaitu pola membangun spiritual, moral, ruh atau jiwa atau biasa disebut dengan tazkiya al-nafs, Membangun jiwa ini sangat penting karena terkait dengan esesnsi kemanusiaan. Di mana dalam filsafat dan tasawwuf, manusia mempunyai dua subtansi yang berbeda (materi) yaitu jasad dan subtansi immateri (jiwa) yang menjadi

\footnotetext{
${ }^{13}$ Imam Abu Hamid al-Ghazali, Kimya' al-Sa'adah, diterj. KH. A. Mustofa Bisri, (Surabaya: Pustaka Progressif, 2002$), 85$.

${ }^{14}$ Imam Zarkasyi \& Abdullah Sahal, Wasiat, Pesan, dan Harapan Pendiri Pondok Modern (Gontor: tth), 21.

${ }^{15}$ Imam Zarkasyi \& Abdullah Sahal, Wasiat, Pesan dan Harapan, 21.

${ }^{16}$ Imam Zarkasyi \& Abdullah Sahal, Wasiat, Pesan dan Harapan, 21.

${ }^{17}$ Imam Zarkasyi \& Abdullah Sahal, Wasiat, Pesan dan Harapan, 21.

18 Jhon W. Satrock, Psikologi Pendidikan (Jakarta Selatan: Salemba Humanika, 2014), 158.
} 
hakikat manusia dan menentukan derajatnya. ${ }^{19}$ Yang dimaksud dengan spiritualisasi pendidikan agama Islam adalah upaya menjiwakan nilai-nilai ajaran Islam (salah satunya nilai kesetaraan) agar menjadi pandangan dan sikap hidup seseorang santri. Sehingga pendidikan agama Islam benar-benar menyatu dan akhirnya menjadi bagian yang dampaknya benar-benar terjadi dalam aspek lahiriah. Dengan kata lain, spiritualisasi pendidikan agama Islam adalah proses menanamkan, membenamkan, dan menyatukan nilai-nilai ajaran Islam ke dalam jiwa terdidik, sehingga nilai tersebut menjadi menyatu dan tampak dalam kepribadian mereka dan terimplementasikan dalam pola hidup mereka. ${ }^{20}$

\section{Integritas Nilai Keislaman dan Keindonesiaan}

Salah satu strategi yang pernah ditawarkan oleh Munawir Sjadzali dalam rangka membangun peradaban di Indonesia adalah reaktualisasikan nilai keislaman dan keindonesiaan, yaitu nilai berketuhanan, nilai kemanusiaan yang adil dan beradab, nilai persatuan dan kesatuan, nilai kebijaksanaan dalam kepemimpinan, dan nilai keadilan. ${ }^{21}$ Dalam penelitian ini ditemukan integritas nilai keislaman dan keindonesiaan melalui pendidikan pesantren yang pada dasarnya ajaran pesantren adalah ajaran kebertuhanan (tauhid) itu sendiri. Tidak ada pesantren yang tidak mendasarkan pada ajaran tauhid. ${ }^{22}$ Bahkan telah dijelaskan bahwa pendidikan pesantren berdiri di atas asas nilai spiritual yang menjiwai setiap santri. ${ }^{23}$

Integrasi nilai keislaman dan keindonesiaan dalam temuan penelitian ini mengandung aspek otonomi dan aspek heteronomy, di mana kedua aspek tersebut terkait satu sama lain dalam menciptakan karakter bangsa yang baik. Kedua aspek tersebut harus selalu bersinergi dan berintegrasi. Aspek otonomi adalah upaya pendidikan yang diimplementasikan melalui pembelajaran, pembiasaan, keteladanan, motivasi, dan penegak aturan. Sementara aspek heteronomi usaha yang dilakukan di lingkungan (luar pendidikan) yakni adanya keadilan sosial ekonomi, penegakan hukum tanpa timbang pilih, keteladanan pimpinan, serta keteraturan norma-norma sosial. ${ }^{24}$

Kedua aspek tersebut jika didialogkan dengan temuan penelitian ini di mana pesantren sebagai lembaga pendidikan yang bergerak pada aspek otonomi dan heteronomi secara simultan dan inheren. Sebab, para santri hidup 24 jam di dalam pesantren maka orientasi dan aktualisasi kedua aspek tersebut dapat digambarkan secara inheren. Di mana pembelajaran klasikal di pesantren memuat aspek otonomi dan kehidupan santri di luar kelas sebagai aspek heteronomi.

\footnotetext{
${ }^{19}$ Mohammad Muchlis Solichin, "Tazkiyah al-Nafs sebagai Ruh Rekontruksi Sistem Pendidikan Islam" Tadris, Volume 4 Nomor 1 2009: 20.

${ }^{20}$ Edi Susanto, "Spiritualisasi Pendidikan Agama Islam: Menuju Keberagamaan Inklusif Pluralistik" Tadrîs: Volume 9 nomor 1 Juni 2014: 84.

${ }^{21}$ Toharuddin, "Nilai-Nilai Keislaman dan Keindonesiaan dalam Membentuk Karakteristik

Peradaban Melayu di Indonesia (Studi Pemikiran Munawir Sjadzali)," Jurnal Intelektualita: Keislaman, Sosial, dan Sains Volume 7, Nomor 1, Juni 2018, 41.

22 Mastuhu, Dinamika Sistem Pendidikan Pesantren (Jakarta: INIS, 1989) 39-40.

${ }^{23}$ Saifurrahman Nawawi, Nilai Pendidikan Sufistik KH Imam Zarkasyi (Yogyakarta: Sukapress, 2018 ), 67.

${ }^{24}$ Toharuddin, Nilai-Nilai Keislaman dan Keindonesiaan, 48.
} 
Mufiqur Rahman, et. al.

Integrasi nilai keislaman dan keindonesian Kebertuhanan atau Ketuhanan Yang Maha Esa merupakan dasar dari keempat sila lainnya. Ketuhanan Yang Maha Esa bermakna bahwa Bangsa Indonesia merupakan Negara yang monotheisme percaya terhadap Tuhan yang satu bukan sebaliknya. Dengan kata lain, negara Indonesia berlandaskan agama. ${ }^{25}$

Dalam Pendidikan Islam, nilai kebertuhanan atau nilai ketauhidan artinya memusatkan nilai-nilai pendidikan kepada Tuhan dengan pembelajaran tauhid (monoteisme) ilmu kalam, yang secara subtansi bukan untuk kepentingan tuhan namun untuk kepentingan manusia itu sendiri. ${ }^{26}$ Materi tauhid dalam kurikulum Islam adalah materi pertama yang diajarkan Rasulullah kepada anak cucunya. Dalam Islam sendiri ketika seorang anak lahir, orang tuanya mendengungkan adzan (kalimat tauhid) di kedua telinga anak tersebut. Al-Ghazali menyatakan bahwa nilai ketuhanan harus diajarkan sedini mungkin kepada anak. M. Natsir juga mengatakan bahwa nilai kebertuhanan adalah materi yang harus ditanamkan kepada sanubari anak, dan meninggalkannya adalah kesalahan besar. ${ }^{27}$

Dalam kajian tafsir nilai kebertuhanan disebutkan dalam QS. Luqman (13): ayat ke 13, 14, 17, 18, dan 19 yang mana dalam ayat tersebut terkandung tiga ajaran pokok, yaitu tentang ketauhidan, akhlak, dan ibadah. bahwa pendidikan Luqman pertama kepada anaknya adalah menjauhi syirik. ${ }^{28}$ Maka pertama, di dalam menanamkan (internalisasi) nilai kesetaraan pesantren mu'ādalah menjadikan tauhid sebagai perhatian dalam proses spritualisasi pendidikan. Teosentris ini kemudian ditransformasikan sebagai nilai yang menjiwai seluruh kegiatan pendidikan. Teosentris juga mengakses rasionalitas, kebebasan dan kesamaan, akan tetapi tetap dalam bingkai nilai-nilai transendental, yang ujungujungnya tetap untuk mendekatkan diri kepada Tuhan. ${ }^{29}$

Kedua, nilai persatuan. Pesantren penuh dengan keberagaman baik dari suku, bahasa, budaya, dan etnis. Keberagaman tersebut bersatu dalam komitmen bersama dalam jiwa pesantren yaitu ukhuwah Islamiyah yang dikuatkan dalam disiplin sosial pesantren. Inilah makna sila persatuan santri. Kiai pesantren memberikan perlindungan kepada segenap santri dengan kehidupan yang nyaman dan semangat persatuan ukhuwah Islamiyah. Kesetaraan dan Perlakuan yang sama pada seluruh santri tanpa memandang latar belakang suku, ras, budaya, maupun etnis.

Nilai persatuan juga termanifestasi dalam budaya kehidupan santri di pesantren. Adanya beberapa kegiatan pesantren yang menunjukkan persatuan bangsa sebagai sila ketiga yaitu seperti budaya demonstrasi budaya antar daerah/konsulat masing-masing santri. Persatuan antar konsulat memberikan makna kekuatan persatuan dalam persaudaraan santri yang terorganisir dengan baik. Dalam organisasi konsulat ini, terdapat nilai ta’awü dan tawashi-di mana santri dapat menjalani proses pendidikan di pesantren dengan baik.

\footnotetext{
${ }^{25}$ Wendy Anugrah Octavian, “Urgensi Memahami dan Mengimplementasikan Nilai-nilai Pancasila dalam Kehidupan Sehari-hari sebagai Sebuah Bangsa” Jurnal Bhinneka Tunggal Ika, volume 5, nomor 2, November 2018: 125.

${ }^{26}$ Lorens Bagus, Kamus Filsafat (Jakarta: Gramedia Pustaka Utama, 2005), 295.

${ }^{27}$ Abd. Haris, Pendidikan Karakter berbasis Tauhid; Sebuah Pendekatan Filosofis (Sidoarjo: Al-Afkar Press, 2012 ), 81.

${ }^{28}$ Ahmad Mushthafa al-Maraghiy, Tafsir al-Maraghy, Jilid 7 (Beirut : dar al-Fikr, 1974).

${ }^{29}$ Ahmad Mushthafa al-Maraghiy, Tafsir al-Maraghy, 94.
} 
Ketiga, nilai kebijaksanaan. Dalam kepemimpinan pesantren mu'ādalah sebagai salah satu lembaga pendidikan menempatkan demokrasi sebagai upaya penegakan hukum dan aturan pesantren. Semua sama tidak dibeda-bedakan, baik santri keturunan Kiai, anak Ustad, atau anak orang kaya, pengusaha semua sama di depan hukum dan peraturan pesantren. Santri berlatar belakang apapun harus mentaati peraturan pesantren yang telah disepakati oleh semua warga pesantren.

Keempat, nilai keadilan sosial yang memiliki makna bahwa setiap warga negara diperlakukan sama tanpa adanya perbedaan suku, ras, agama, bahasa, kaya dan miskin, maupun jabatan. Semua warga negara harus diperlakukan adil oleh negara. ${ }^{30}$ Nilai keadilan pesantren tergambar dalam budaya kesetaraan sosial yang tetap berdasar pada local culture pesantren.

\section{Integrasi Nilai dan Budaya Sosial berdasarkan Local Culture Pesantren}

\section{Nilai Kesetaraan dalam Budaya Pengabdian}

Secara ontologis pesantren mu'ādalah dalam penelitian ini memiliki arah dan tujuan yaitu menjadi perekat umat dan keumatan. Kata perekat umat ini adalah istilah yang dipilih oleh TMI AlAmien Prenduan dengan beberapa pemikiran yang mendasar. Istilah tersebut diambil dan dijadikan sebuah adagium yang melekat pada jiwa Pesantren Al-Amien yang akhirnya menjadi positioning TMI Al-Amien dalam bersikap secara politis baik keluar maupun ke dalam (dalam proses pembelajaran).

TMI dalam konteks salah satu tujuan pokoknya adalah pengabdian kepada umat. Kata perekat umat yang menjadi jargon TMI Al-Amien, memilih kata perekat umat setelah berupaya mencoba mencari istilah dalam Islam yang kiranya cocok atau eligible. Istilah tersebut diyakininya paling cocok diambil, untuk bisa dianalogikan dengan kata bersayap agar dalam pembicaraan lebih lanjut berada pada frame of reference yang sama yaitu Islam sebagai perekat umat menjadi sebuah terminologi qur'ani.

Bahwa secara etimologi "perekat" berarti pelaku dari kerja "melekatkan, melengketkan, atau menggabungkan" dua benda atau lebih yang sejenis maupun tidak sejenis. Sedangkan kata "umat" merupakan padanan kata masyarakat stau sekelompok orang, yang biasanya dipergunakan secara khusus untuk orang-orang Islam. Karena secara terminologi, kata "perekat umat" seharusnya dikonotasikan pada upaya-upaya memadukan, menyatukan, mendamaikan umat Islam yang berada pada kondisi berbeda (ikhtilāf), bertikai (tanazu*), bahkan mungkin dalam kondisi berperang atau konfrontasi fisik ( qitāl). ${ }^{31}$

Pengabdian ini ketika didialogkan dengan istilah-istilah yang ada di dalam al-Quran setidaknya akan mengakomodir dan memanifes istilah yang disebut dengan ta'aruf, silaturrahimn, dan is/âh. Istilah tersebut konotatif dan subordinatif dengan hakikat dan misi perekat umat yang diistilahkan oleh Kiai Idris dalam konteks kehidupan berpolitik, sosial dan keagamaan lebih-lebih

\footnotetext{
${ }^{30}$ Wendy Anugrah Octavian, Urgensi Memahami dan Mengimplementasikan Nilai-nilai Pancasila, 127.

${ }^{31}$ Mohammad Idris Djauhari, Alumni Pesantren sebagai perekat Umat (Sumenep: Mutiara Press, 2005$), 3$.
} 
Mufiqur Rahman, et. al.

dalam konstelasi pergaulan antar manusia. Berikut ini adalah pemikiran dan konsep Kiai Idris dalam politik perekat umat dengan mengkoneksikan badanannya secara fungsional sebagai misi politik TMI Al-Amien Prenduan:

Tebel 01: Nilai Perekat Umat dan Keumatan ${ }^{32}$

\begin{tabular}{|c|c|}
\hline Nilai & Fungsi dan misi \\
\hline Ta’aruf & $\begin{array}{l}\text { Seorang perekat umat masih berada pada tahap permulaan, tahap } \\
\text { ketika ia tidak banyak tahu tentang situasi umat yang dihadapinya di } \\
\text { tengah keragaman etnis dan budaya masyarakat. Karena itu langkah } \\
\text { pertama yang harus dilakukan adalah berkenalan dengan sebanyak- } \\
\text { banyaknya umat dan berusaha untuk kenal dengan keadaan mereka } \\
\text { secara mendalam, baik secara lahiriyah maupun batiniyah, individual } \\
\text { maupun sosial. Semakin banyak wilayah ta'arufnya semakin besar } \\
\text { pula peluang yang dimilikinya untuk melakukan penilaian dan } \\
\text { evaluasi social dan politik berdasarkan kriteria "atqākum”. Seperti } \\
\text { disebutkan pada QS. Al-Hujurat ayat 13: "Hai manusia, Sesungguhnya } \\
\text { Kami menciptakan kamu dari seorang laki-laki dan seorang } \\
\text { perempuan dan menjadikan kamu berbangsa - bangsa dan bersuku- } \\
\text { suku supaya kamu saling kenal-mengenal. Sesungguhnya orang yang } \\
\text { paling mulia diantara kamu disisi Allah ialah orang yang paling taqwa } \\
\text { diantara kamu. Sesungguhnya Allah Maha mengetahui lagi Maha } \\
\text { Mengenal”. }\end{array}$ \\
\hline Silaturrahimı & $\begin{array}{l}\text { Fungsi yang kedua ini, seorang perekat umat sudah berada pada } \\
\text { posisi yang aktif masuk ke dalam suatu kelompok yang tumbuh dan } \\
\text { berkembang di tengah umat. Sementara ia berada pada satu pihak, } \\
\text { saudara-saudaranya yang seiman berada pada pihak lain yang tidak } \\
\text { saja berbeda secara teknis, bahkan sering kali juga berbeda pendapat, } \\
\text { kepentingan, dan tujuan. Maka untuk menjalankan perannya sebagai } \\
\text { perekat umat secara benar dan proporsional, maka dia dituntut } \\
\text { secara aktif dan kreatif menjalin hubungan serta menjembatani } \\
\text { perbedaan-perbedaan (melaksanakan silaturrahmi) antara dirinya } \\
\text { dan orang lain atau antara kelompok dan kelompok yang lain. Hal ini } \\
\text { dapat disinyalir dala QS. An-Nisa': } 1 \text { dan QS. Ar-Ra'ad: 19-21. }\end{array}$ \\
\hline Islfāh & $\begin{array}{l}\text { Di sini seorang perekat umat harus berada pada posisi netral sebagai } \\
\text { juru damai, wasit, dan mediator yang hanyak memihak pada }\end{array}$ \\
\hline
\end{tabular}

\footnotetext{
${ }^{32}$ Mohammad Idris Djauhari, Alumni Pesantren sebagai Perekat Umat, 3-7.
} 


\begin{tabular}{|l|l|}
\hline kebenaran (keadilan dan taqwa). Pada QS. Al-Hujurat: 9-10 Allah \\
menggubakan kata “islāh bainahumā” pada situasi ketika ada dua \\
(atau lebih) kelompok orang mukmin sedang dalam keadaan bertikai \\
atau berperang. Proses islah ini hanya akan berlangsung di antara \\
orang-orang atau kelompok yang sama-sama memiliki komitmen dan \\
I'tikad baik (good will) untuk menyelesaikan konflik dengan cara-cara \\
yang damai. Ayat ini juga menyiratkan juga bahwa proses Islah harus \\
didasarkan pada kesadaran "ukhuwah" di antara umat. Semua proses \\
ini wajib dilakukan oleh setiap muslim secara proaktif dalam berbagai \\
situasi dengan melakukan penyesuaian-penyesuaian.
\end{tabular}

Berbasis kepada nilai-nilai di atas, maka santri dan alumni Pesantren Muadalah hukumnya wajib dan dituntut bertindak berdasarkan tiga nilai dan fungsi perekat umat (ta'aruf, silaturrahimn dan isfāhh) pada satu situasi santri dan alumni TMI al-Amien dituntut melakukan fungsi ta'aruftetapi pada situasi yang lain mereka dituntuk melakukan fungsi sebagai penghubung atau sebagai pendamai (al-Muslih) antara dua pihak yang bertikai. Tiga dimensi nilai politik dan hukum Pesantren ini dalam merangkai sistem pendidikan dan pembelajaran, sehingga materi ajar juga mengacu kepada nilai-nilai tersebut. ${ }^{33}$

Nilai ta'aru‡, silaturrahim̄n dan isfāh dapat dinyatakan sebagai bentuk nilai kesetaraan dalam program kegiatan masyarakat, di mana terdapat kesamaan atau kesetaraan hak untuk mengikuti dan berpartisipasi dalam kegiatan pengabdian masyarakat. UNESCO menyebutnya sebagai sebuah pesan bahwa setiap anak memiliki masalah dan masalah tersebut harus sama every leaners matters and matters equally, di mana masalah pengabdian di pesantren muadalah adalah masalah yang sama yang harus ditempuh oleh santri pesantren mu'ādalah. Sebagaimana menurut UNESCO bahwa praktek kesetaraan dalam sebuah pendidikan menjadi tanggung jawab moral bagi pemangku kebijakan dalam satuan pendidikan bahkan juga pemerintah. ${ }^{34}$ Pesantren mu'ādalah (TMI Al-Amien) menempatkan pengabdian santri sebagai salah satu bentuk syarat dan tanggung jawab moral kepada aturan pesantren yang telah menetapkan misi utama pesantren adalah mengabdi kepada masyarakat. Dalam hal ini, pengabdian sebagai bentuk pendidikan kesetaraan yang menjamin kesetaraan dan keadilan dalam pendidikan dan pembelajaran bahwa anak memiliki hak yang sama dalam pendidikan. ${ }^{35}$ Misalnya dalam pengabdian di masyarakat santri pesantren mu'ādalah berperan sebagai guru di sebuah lembaga yang ditempati, menjadi penceramah agama

\footnotetext{
${ }^{33}$ Mohammad Idris Djauhari, Alumni Pesantren sebagai Perekat Umat, 3-7.

${ }^{34}$ UNESCO (United Nation, Educational, Scientific, and Cultural Organization, A Guide for Ensuring Inclusion and Equity in Education (France : UNESCO, 2017), 12.

${ }^{35}$ Mohammad Idris Djauhari, Alumni Pesantren sebagai Perekat Umat, 7.
} 
Mufiqur Rahman, et. al.

pada acara sarwe'en ${ }^{36}$ masyarakat, menjadi khotib Jum'at. Bahkan mereka terlibat dalam kegiatan sosial masyarakat lainnya seperti gotong royong pembersihan lingkungan, perbaikan jalan dan tidak jarang mereka juga ikut hadir dalam acara kematian dan tengka ${ }^{37}$ lainnya.

Nilai ta'aruf, silaturrahimı dan is/ăh sebenarnya tidak hanya dapat ditemukan hanya pada program pengabdian, namun juga kegiatan lainnya, baik program intra, ko-kurikuler dan ekstrakurikuler. Salah satunya melalui kegiatan kajian Masā' al Diniyah pada pesantren TMI AlAmien, di mana dalam kegiatan forum kajian Masā' al Diniyah ini antar santri melakukan ta'aruf, silaturrahimn dan isflăh. Karena dalam forum kajian ini masing-masing anggota dapat melakukan diskusi dan saling melakukan islah apabila dalam kajian terjadi kesalahan.

Nilai ta’aruf, silaturrahim̧ dan is/āh di atas termanifestasi dalam kegiatan pendidikan pesantren muadalah di Madura secara langsung maupun tidak langsung, yang pada hakikatnya merupakan lokal kultur pesantren terlebih juga menjadi kultur masyarakat Madura. Kumpulan rumah tradisional Madura dikenal dengan nama "taniyan lanjheng" 38 (halaman panjang) yang salah satu fungsinya adalah untuk mempererat tali silaturahim antar keluarga dalam masyarakat. Bahkan pribahasa yang bermakna: berkata baik dan sopan antar masyarakat. ${ }^{39}$ Artinya masyarakat Madura mengedepanan nilai silaturrahmi dengan tutur kata yang halus dan sopan. Seperti kata "akotak tak atellor" (berkokok tapi tidak bertelur); sebuah perumpamaan tentang orang berbicara tinggi, namun tidak menghasilkan apa apa. Ada juga kata-kata "akanta lesson bhurto" (seperti lessung yang berlubang di bagian bawahnya); sebuah perumpamaan orang yang boros yang hasil kerjanya cepat habis. ${ }^{40}$

\section{Nilai Kesetaraan dalam budaya kaderisasi}

Dalam ayat al Qur'an dan Hadis banyak sekali anjuran Nabi terkait dengan kesetaraan dan kesimbangan hidup yang dapat dijadikan sikap hidup setara dan seimbang. Tolhah Hasan, menyebutkan ada enam sikap yang seharusnya menjadi sikap setiap manusia: pertama adalah sikap untuk tidak berlebihan di dalam hal makan dan minum; kedua, mereka orang-orang yang beriman kepada Allah dan hal ghaib menafkahkan sebagai rizkinya yang telah dianugrahkan kepada mereka;

\footnotetext{
${ }^{36}$ Kegiatan seperti tahlilan masyarakat biasanya dilakukan setiap malam jumat. Selain kata Sarwe'en juga disebut dengan istilah kompolan, koloman, sabelesendst. yang artinya sama dengan sarwe'en.

${ }^{37}$ Tengka adalah sikap masyarakat saat terjadi kematian, ulang tahun, imtihanan, rokat tase' dan acara lainnya yang membutuhkan sumbangan masyarakat untuk mengurangi beban ahlil bait.

${ }^{38}$ Walaupun Tanian lanjhang kini sudah mulai tergerus, Dalam tradisi bangunan rumah misalnya, Kini, mulai jarang bangunan rumah yang khas Madura, seperti romabangsal, roma pegun dan roma pacenan, bahkan di pelosok pedesaan pulau Madura. Dalam tradisi lama, tipe roma bangsal biasanya dimiliki oleh kalangan priyayi Madura, seperti klebun [kepala desa]. Sementara, tipe roma pegun mencerminkan bahwa empunya adalah kalangan menengah dari segi ekonomi dan tipe roma pacenan adalah rumah kalangan orang kebanyakan. Dengan melihat model arsitektur dan struktur ornamental rumah orang-orang Madura tempo doeloe, tampak jelas adanya perbedaan kelas sosial dalam masyarakat Madura. Baca Edi Susanto, Revitalisasi nilai luhur Tradisi Lokal Madura (KARSA, Vol. XII No. 2 Oktober 2007), 97.

${ }^{39}$ Mohammad Tidjani, Membangun Madura (Jakarta : Taj Publishing, 2008), 14.

${ }^{40}$ Mohammad Tidjani, Membangun Madura, 19.
} 
ketiga, mereka yang ketika membelanjakan harta tidak boros dan berlebihan dan tidak kikir; keempat, mencintai orang sewajarnya; kelima, menunaikan amanat kepada yang memberi amanah dan jangan berkhianat; keenam, apabila meninggalkan ahli waris dengan keadaan kaya itu lebih baik daripada mereka dalam keadaan miskin, melarat dan meminta-minta kepada orang lain. ${ }^{41}$

Keseimbangan ini dijelaskan di dalam alquran surah al-Qasł̧ jayat 77, bahwa nilai keadilan dan kesamaan disebut Maskuri sebagai salah satu nilai dalam misi Islam yaitu rahmatan li al-alamikr. ${ }^{42}$ Maka, akses mendapatkan kesetaraan dalam proses pendidikan adalah dalam rangka mewujudkan nilai dan misi islam tersebut. Dalam catatan Maitzegui-Onate \& Santibanez-Gruber, pada tahun 2008 menuliskan sebuah artikel tentang akses pendidikan dalam masyarakat multicultural. Mereka mengajukan sebuah konsep kesetaraan (equity), yang pertama adalah kesempatan dan hak yang sama secara hukum dalam akses pendidikan di sekolah (opportunity or legally recognised rights). Kedua, akses berangkat ke sekolah (access to school). Ketiga, pelayanan atau model dan arah pendidikan (treatment or educational models and measures) dan hasil atau kesempatan untuk sukses (results or opportunity for success). ${ }^{43}$

Dalam rangkaian memperoleh dan mendorong kesempatan dan hak yang sama secara hukum dalam akses pendidikan di pesantren mu'ādalah dan juga untuk pelayanan atau model dan arah pendidikan (treatment or educational models and measures) serta kesempatan untuk sukses bersama (results or opportunity for success). Pesantren mu'ādalah menerapkan sistem kaderisasi ${ }^{44}$ atau yang dikenal dengan istilah "patah tumbuh hilang berganti". Kaderisasi ini dilakukan melalui prinsip dan nilai keadilan dan kesamaan (kesetaraan), sebab sejatinya kaderisasi adalah pola pendidikan dan pembinaan lanjutan. ${ }^{45}$ Walaupun politik kaderisasi ini dilakukan untuk keberlangsungan sebuah sistem kepemimpinan dan pelayanan pesantren secara estafet dan memandang semua santri memiliki kesempatan dan hak yang sama dalam pendidikan kepemimpinan dan manajemen. Sehingga para santri dilatih menjadi manajer dan juga pemimpin yang juga memiliki jiwa dan nilai kesetaraan (keadilan dan kesamaan) dalam pendidikan.

Prinsip-prinsip keadilan dan kesamaan dalam kaderisasi TMI Al-Amien sebagai pesantren mu'ādalah pada hakikatnya merupakan pendidikan dan pembinaan secara merata (menganut pertimbangan keadilan dan kesamaan) baik bagi santri, abituren (alumni yang mengabdi di dalam pesantren biasanya dilakukan seleksi secara adil) dengan beberapa syarat yang disepakati, dan juga

\footnotetext{
41 Muhammad Tholhah Hasan, Pendidikan Multikultural sebagai Opsi Deradikalisasi (Malang: Unismapress 2017), 7172.71-72.

${ }^{42}$ Maskuri Bakri, Islam, Pendidikan Multikultural, dan Budaya Damai; Telaah Kritis tentang Indahnya Perbedaan dalam Negara Bangsa( Malang: Lembaga Penerbitan Unisma, 2014), 131.

${ }^{43}$ Luciana Castellia, Serena Ragazzia \& Alberto Crescentinia, International Conference on Education and Educational Psychology (ICEEPSY 2012)Equity in Education: a General Overview (Procedia - Social and Behavioral Sciences 69 ( 2012 ) $2243-2250,2246$.

${ }^{44}$ Tentang kaderisasi dalam pengertian sebuah proses yang meliputi rekrutmen dan pembinaan dalam sebuah sistem pendidikan pesantren untuk menjadi penurus tongkat estafet kepemimpinan Baca Daryanto , Administrasi Pendidikan (Jakarta: PT Rineka Cipta, 1998), 289.

${ }^{45}$ Tim Sekretariat Pesantren Al-Amien, Profil singkat Pondok Pesantren Al-Amien Prenduan, 25
} 
Mufiqur Rahman, et. al.

dilakukan melalui organisasai alumni bernama Ikatan keluarga besar al-Amien Prenduan (IKBAL). Pembinaan ini dilakukan agar para santri dan alumni mampu memegang posisi kunci (key possision) baik di pesantren maupun di tengah masyarakat sebagai perekat umat atau pemimpin umat (mundzir al-Qaum) yang ahli hukum agama (mutafaqqih fi al-dirz). ${ }^{46}$

Kaderisasi ini dilakukan secara berkesinambungan dengan prinsip pendidikan TMI al-Amien, bahwa arah pendidikan di pesantren ini adalah mencetak santri yang multi terampil untuk hidup berjasa, berkembang dan mandiri di tengah masyarakat. Maka manajemen pendidikan di pesantren ini dilakukan atas dasar konsep manajemen berbasis lembaga (institution based management) dan konsep pendidikan berbasis masyarakat (community based education). Sehingga semboyan yang ada di pesantren ini adalah "tiada hari tanpa beribadah, belajar, berlatih, dan berprestasi. ${ }^{47}$ Politik kaderisasi ini menurut salah satu informan kunci yang menjadi satu muara kebijakan adanya hukum (kewajiban) bagi para alumni untuk mengabdi di tengah masyarakat setelah menyelesaikan studinya di pesantren setidaknya 1 tahun, sebagai salah satu syarat mendapatkan ljazah TMI.

Diagram 1: Sistem Kaderisasi Pesantren Muadalah (TMI AI-Amien)

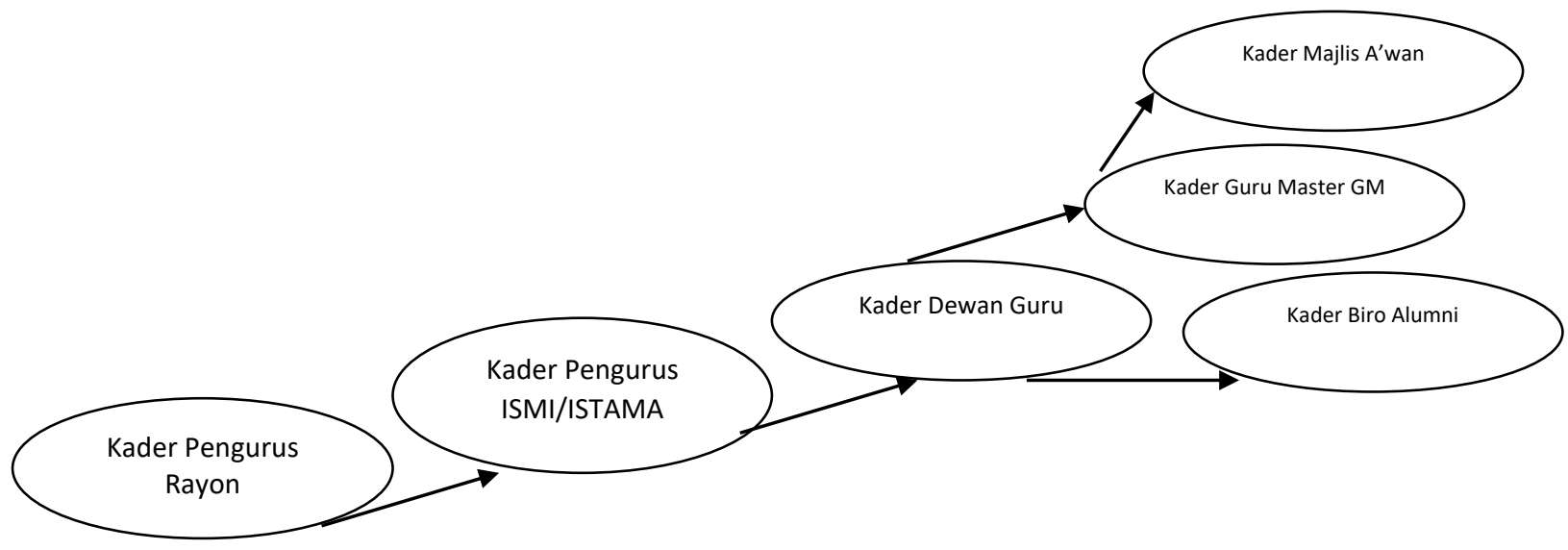

Model kaderisasi pesantren mu'ādalah (TMI Al-Amien) secara spesifik ada sedikit perbedaan dalam melakukan metode atau cara regenerasi atau kaderisasi sesuai dengan ketokohan Kiai yang menjadi ciri khas Kiai tertentu di dalam melakukan sistem kaderisasi. ${ }^{48}$ TMI lebih menekankan kepada manajemen kaderisasi atau apa yang disebut dengan kaderisasi manajerial dengan pola dan sistem pendidikan yang memang menekankan arah pendidikannya dengan wawasan kepemimpinan dan kaderisasi.

\section{Nilai Kesetaraan dalam Budaya Demokrasi}

Pesantren mu'ādalah berasas pada ajaran Islam, yang secara filosofis dan sosial revolutif memberikan ruang selebar-lebarnya akan terwujudnya persaudaraan yang universal (universal brotherhood), adanya kesetaraan (equality) dan keadilan sosial. Kesetaraan merupakan bagian dari

\footnotetext{
${ }^{46}$ Tim Sekretariat Pesantren Al-Amien, Profil Singkat, 25.

${ }^{47}$ Tim Sekretariat Pesantren Al-Amien, Profil Singkat, 23.

${ }^{48}$ Tentang ciri pesantren yang dipengaruhi oleh pribadi Kyai baca Manfred Ziemek, Pesantren dalam perubahan sosial (P3M Penghimpunan Pengembangan Pesantren dan Masyarakat, 1985 ), 97.
} 
prinsip demokrasi. Salah satu bentuk eksistensial dari sebuah demokrasi adalah kesetaraan atau kesamaan, yang orientasinya adalah memperlakukan semua orang sama dan sederajat dalam konteks demokrasi. ${ }^{49}$

John Dewey, mengatakan bahwa demokrasi adalah model kehidupan sosial dan tidak hanya berbicara soal politik ansich. Demokrasi dalam implementasinya membutuhkan peran dan kerjasama semua pihak, seperti institusi sosial, lembaga politik, ekonomi, lembaga pendidikan, saintis, lembaga agama artistik dan semua warga dalam sebuah negara. Inilah demokrasi dalam sudut pandang yang komprehensif dan bersifat integratif konektif antara yang satu dengan yang lainnya. ${ }^{50}$ Maka makna demokrasi adalah sangat luas dan tidak hanya menyoal soal pesta politik saja. Dewey meyakinkan bahwa untuk mewujudkan demokrasi perlu peran serta masyarakat, termasuk juga lembaga pendidikan.

Pesantren mu'ādalah sebagai salah satu lembaga pendidikan menempatkan demokrasi sebagai upaya penegakan hukum dan aturan pesantren, semua sama tidak dibedaka-bedakan, baik santri keturunan Kiai, anak Ustad, atau anak orang kaya, pengusaha semua sama di depan hukum dan peraturan pesantren. Santri berlatar belakang apapun harus menaati peraturan pesantren yang telah disepakati oleh semua warga pesantren.

"Dalam hal penyusunan formatur kepengurusan Ikatan Santri Mualimin al-Islamiyah ISMI dilakukan dengan cara yang cara demokratis. Di mana setiap santri boleh mencalonkan diri sebagai ketua organisasi santri. Namun ada syarat-syarat yang harus dipenuhi sebagai calon formatur ketua ISMI atau calon kandidat. Para formatur diambil sesuai dengan hasil pemilihan santri. Setelah itu Kiai beserta pembantunya memberikan nasehat kepada formatur terpilih oleh santri tersebut. Di sini demokrasi berbasis pesantren TMI Al-Amien dilakukan tanpa ada praktek-praktek yang melanggar hukum fiqih atau syariat agama. Demokrasi ini disebut sebagai demokrasi terpimpin, karena Kiai masih memegang keputusan akhir dari sebuah kebijakan organisasi santri (ISMI). ${ }^{51}$

Dalam Islam demokrasi disebut dengan Istilah shurā, berasal dari kata kerja shawara yushawiru yang berarti menjelaskan, menyatakan atau mengajukan dan mengambil sesuatu. Ada bentuk-bentuk lain yang berasal dari kata kerja shawara, yaitu ashara (memberi isyarat), tashawara (berunding, saling bertukar pendapat), shāwir (meminta pendapat, musyawarah) dan mustaship (meminta pendapat orang lain). Shurā atau musyawarah adalah saling menjelaskan dan merundingkan atau saling meminta dan menukar pendapat mengenai suatu perkara. ${ }^{52}$

\footnotetext{
${ }^{49}$ Sabaruddin, NIlai-nilai demokrasi dalam pendidikan di Pesantren : Studi kasus pesantren-pesantren di Yogyakarta (Yoyakarta: Disertasi UINSUKA, 2011), 345.

${ }^{50}$ Barbara J, Tayor Bacon. Education's role in democracy; the power of pluralism, Etica \& Politica / Ethics \& Politics, XII, 2010, 1, 135. Baca juga Mufiqur Rahman, "Demokrasi dalam filsafat pendidikan barat dan Islam :kajian tentang nilainilai demokrasi dan implementasinya dalam konteks pendidikan Indonesia," Cendekia: Jurnal Studi Keislaman Volume 3 nomor2 Desember 2017), 14.

${ }^{51}$ Hamzah, Wawancara 6 September 2019.

${ }^{52}$ Muhammad Ichsan, Demokrasi dan Syura perfpektif Islam dan Barat. Substantia, Volume 16 Nomor 1, April 2014, 6.
} 
Mufiqur Rahman, et. al.

Oleh karena itu, dalam penegakan disiplin pesantren, TMI Al-Amien mengedepankan asas musyawarah dalam setiap pengambilan keputusan. Politik agar seluruh santri mengikuti kegiatan pesantren serta harus patuh terhadap aturan dan sunnah pesantren tanpa terkecuali, baik santri dari kalangan elit (orang kaya) atau anak pejabat, maka kedua pesantren mu'ādalah ini menerapkan surat perjanjian atau surat kesepakatan sebelum santri masuk dan diterima di pesantren. Mereka dan para orangtua (wali santri) harus menanda tangani surat kesepakatan tersebut. Salah satu butir perjanjiannya adalah santri wajib patuh dan taat kepada kebijakan dan aturan pesantren serta wajib mengikuti seluruh kegiatan pesantren. ${ }^{53}$

Surat kesepakatan atau kesepahaman terhadap pesantren mu'ādalah tersebut merupakan bentuk nilai demokrasi dan kesetaraan (egalitarialisme) yang juga menganut unsur nilai perlindungan pesantren mu'ādalah serta nilai ketertiban. Parmudi dalam Mufiqur Rahman menyebutkan 14 Nilai demokrasi terkait dengan ini bahwa demokrasi berpengaruh terhadap pendidikan dengan nilai demokrasi berikut yaitu 1. Nilai kesetaraan (egalitarialisme) 2. Nilai penghargaan terhadap hak-hak asasi. 3. Nilai perlindungan (protection) 4. Nilai keberagaman (pluralisme) 5. Nilai keadilan (justice) 6. Nilai toleransi 7. Nilai kemanusiaan 8. Nilai ketertiban 9. Nilai penghormatan terhadap orang lain. 10. Nilai kebebasan 11. Nilai penghargaan terhadap kepemilikan. 12. Nilai tanggung jawab 13. Nilai kebersamaan 14. Nilai kemakmuran karena demokrasi mengandung aneka ragam nilai tersebut, maka demokrasi menempati posisi sangat strategis dalam menyeimbangkan berbagai nilai itu. ${ }^{54}$

Maka untuk mengajarkan nilai tersebut di atas, peran lembaga pendidikan sangatlah penting untuk dijadikan lembaga/institusi yang menyampaikan pengetahuan. Sehingga demokrasi dapat berpenampilan sebagai "mediator" yang menjadi sarana untuk menengahi berbagai pertentangan nilai dalam kehidupan manusia. ${ }^{55}$

Untuk menegakkan disiplin, pesantren mu'ādalah melakukan sistem "santri mengatur santri" yaitu santri senior yang dipilih oleh santri melalui mekanisme pemilihan demokratis untuk menjadi pengurus organisasi santri (organtri). TMI Al-Amien memberikan kepercayaan sepenuhnya kepada guru dan panitia seleksi pengurus, demokrasi pesantren mu'ādalah masih cendurung mengedepankan musyawarah tidak serta merta demokrasi murni yaitu intervensi Kiai dan pembantunya masih inten untuk memberikan pertimbangan-pertimbangan. Di sini, biasanya Kiai melakukan istikharah untuk menentukan calon yang dipilih santri. ${ }^{56}$

Untuk menggambarkan distingsi demokrasi yang dianut pada kedua pesantren mu'âdalah ini peneliti ingin mendeskripsikannya bahwa TMI Al-Amien dalam menentukan ketua Ikatan santri

\footnotetext{
${ }^{53}$ Hamzah, Wawancara 6 September 2019.

${ }^{54}$ Mufiqur Rahman, Demokrasi dalam Filsafat Pendidikan Barat dan Islam: Kajian tentang Nilai-nilai Demokrasi dan Implementasinya dalam Konteks Pendidikan Indonesia (Cendekia: Jurnal Studi Keislaman Volume 3 nomor 2 Desember 2017), 14. Baca juga Mochammad Parmudi, Islam dan Demokrasi di Indonesia; Dalam Perspektif Pengembangan Pemikiran Politik Islam (Laporan Hasil Penelitian individual, DIPA 2014), 16.

${ }^{55}$ Mufiqur Rahman, Demokrasi dalam Filsafat Pendidikan Barat dan Islam, 20.

${ }^{56}$ Hamzah Arsa (Kepala Marhalah Aliyah TMI Al-Amien), Wawancara pada 15 Desember 2019.
} 
Muallimin Al-Islamiyah ISMI dilakukan dengan cara demokrasi semi liberal atau yang disebut presidium, di mana seluruh santri menjadi konstituen yang berhak memilih presiden/ketua. Panitia pemilihan presiden ISMI dilakukan layaknya demokrasi di Indonesia, ada debat capres, ada pemaparan visi dan misi. Setelah terpilih oleh santri, baru Kiai mengukuhkan dan melantik calon terpilih serta memberikan arahan dan pembekalan. Suasama pemilihan presiden ISMI berlansung hangat penuh dengan peran konsulat atau dukungan daerah masing-masing.

Model demokrasi di pesantren mu'ādalah adalah demokrasi yang warnai oleh local wisdom; gotong royong, musyawarah, untuk mufakat kemudian mengadopsi demokrasi Barat, dan dipadukan dengan Islam. Lalu terbentuklah model demokrasi ala pesantren dengan teori interconnected entity yang pernah dipopulerkan oleh Parmudi, yaitu secara sederhana demokrasi pesantren bersumber dari Islam kemudian dipadukan dengan local wisdom pesantren. Kemudian mengadopsi demokrasi Barat, yang menjadi jembatan terbentuknya model interconnected entity. ${ }^{57}$

Berikut ini adalah gambar polarisasi demokrasi pesantren mu'ādalah dengan teori interconnected entity. Namun dalam pandangan peneliti pola demokrasi yang ada di pesantren sangat unik dan tidak dapat diformulasikan secara general. Pesantren memiliki pola demokrasi yang menurut peneliti menjunjung tinggi nilai demokrasi pancasila dengan muatan sila yang kelima. Yaitu demokrasi yang dijalankan berdasarkan nilai pancasila yang berasaskan musyawarah dan mengutamakan kepentingan dan maslahat pesantren. Maka interconnected entity dalam demokrasi pesantren tidak dapat dipisahkan dengan local wisdom di mana Kiai menjadi penentu akhir dalam proses demokrasi di pesantren.

\section{Diagram 2: Demokrasi Pesantren Mu’ādalah dalam Kerangka Entitas Terkoneksi}

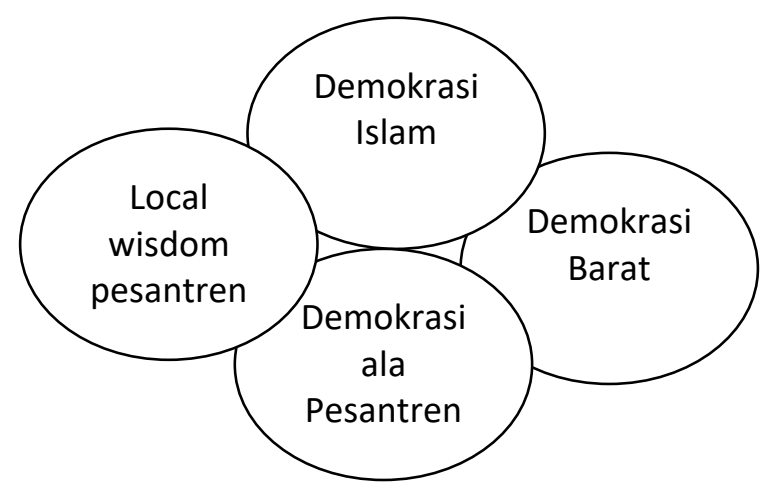

Demokrasi Pancasila yang dianut di pesantren mu'ādalah yang berbasis kepada local wisdom pesantren dalam terminologi Nurcholis Madjid disebut sebagai lembaga yang tidak hanya identik dengan makna keislaman, tetapi juga mengandung makna keaslian Indonesia (indigenous). Dan sebagai lembaga indigenous, pesantren berkembang sesuai dengan sosiologis masyarakat sekitarnya. ${ }^{58}$ Maka nilai demokrasi dalam pesantren mu'ādalah tidak lepas dari peran dan keadaan sosiologis Kiai

\footnotetext{
${ }^{57}$ Mochammad Parmudi, Islam dan Demokrasi Di Indonesia, 17.

${ }^{58}$ Azyumardi Azra, Pendidikan Islam: Tradisi dan Modernisasi Menuju Millennium Baru ( Jakarta: Logos Wacana Ilmu, 2002), 108.
} 
Mufiqur Rahman, et. al.

sebagai leader pesantren dan masyarakat sekitar pesantren. Walaupun pesantren disebut sebagai sub kultur $^{59}$ masyarakat dengan pola total institution.

Sebagaimana demokrasi, dalam penegakan disiplin, dilakukan dengan siasat institusi total (total institution)..$^{60}$ Di mana para santri hidup selama 24 jam di lingkungan pesantren yang jauh dari jangkauan kehidupan masyarakat umum. Sehingga Pesantren TMI Al-Amien dapat menegakkan disiplin pesantren secara totaliter tanpa campur tangan masyarakat apalagi orangtua santri. Para santri "dipaksa" hidup secara normal ala pesantren dengan peraturan pesantren yang sangat ketat. Sehingga tidak semua santri dapat menjalani pola kehidupan ala pesantren ini, dan beberapa dari mereka yang tidak kuat, harus menangis dan meminta pulang.

Tentang sanksi (punishment), semua sanksi atau hukuman yang diterapkan di TMI PP Al-Amien dan DMI Banyuanyar dengan maksud dan tujuan yaitu untuk pendidikan itu sendiri. Pertama, untuk isfāa $h$ dan perbaikan bagi santri yang melanggar disiplin. Kemudian sebagai peringatan supaya yang bersangkutan menyadari kesalahannya dan tidak mengulangi lagi. Kedua, untuk tegaknya disiplin pondok, sehingga tidak ada santri yang dapat meremehkan dan mempermainkan disiplin pondok. Ketiga, untuk cermin perbandingan bagi para santri lainnya agar mereka tidak melakukan pelanggaran atau kesalahan serupa. ${ }^{61}$

Nilai keadilan dalam penentuan sanksi terhadap pelanggaran yang dilakukan santri TMI AlAmien Prenduan dibuktikan dengan adanya kategorisasi pelanggaran disiplin, di mana sanksi diberikan sesuai dengan pelanggaran yang dilakukan apakah tergolong rendah, menengah atau berat. Biasanya santri yang sering melanggar akan mendapat peringatan, (biasanya dipanggil orangtuanya) dan apabila masih melakukan pelanggaran lagi, maka santri tersebut dikembalikan kepada orangtuanya. Kemudian jika sudah diputuskan dikeluarkan (dikembalikan kepada orang tuanya), maka orangtua atau wali dari santri tersebut tidak dapat lagi berkompromi atau bernegosiasi dengan pihak pesantren. Di sini nampak betapa penegakan disiplin ini berlaku untuk semua santri tanpa terkecuali. ${ }^{62}$

Deskripsi tentang nilai demokrasi pesantren mu'ādalah dengan varian nilai demokrasi yang telah disebutkan di atas mencerminkan bahwa pesantren TMI Al-Amien Prenduan menunjukkan responmya dalam menghadapi berbagai perubahan dan tantangan. Para eksponen pesantren bukan serta merta menelan atau menerima begitu saja atau tergesa-gesa mentransformasikan nilai demokrasi dalam kelembagaan pesantren untuk menjadi lembaga pendidikan Islam dengan modernitas sepenuhnya atau menjadi lembaga tradisional dengan sepenuhnya. Namun yang terjadi

\footnotetext{
${ }^{59}$ Ada tiga aspek pesantren disebut subkultur; Pola kepemimpinan pesantren yang mandiri, tidak terkooptasi dengan Negara, kurikulum yang mandiri dengan menggunakan kitab klasik dan sistem nilai yang ada di pesantren merupakan manivestasi dari masyarakat luas. Baca Abdurrahman Wahed, Prospek pesantren sebagai lembaga pendidikan dalam Sonhaji Sholeh (Jakarta: P3M, 1988), 279.

${ }^{60}$ Mohammad Hefni, Penerapan Total Institution Di Pondok Pesantren Al-Amien Prenduan Sumenep (KARSA, Vol. 20 No. 1 Tahun 2012), 44.

61 Jakfar Shodiq, Wawancara 16 Januari 2019

62 Nazmi, Wawancara 16 Januari 2019.
} 
adalah sikap kehati-hatian dan cenderung mempertahankan kebijakan Kiai secara hati-hati. Kiai menerima pembaharuan (modernitas) dengan skala yang terbatas. Sebatas untuk bisa tetap survive. ${ }^{63}$ Oleh karenanya TMI Al-Amien masih mempertahankan kata "pesantren" untuk menunjukkan internalisasi sikap keaslian (indigenous) kelembagaannya.

Kebutuhan pesantren mu'ādalah secara khusus terhadap gaya kepemimpinan Kiai yang demoktratis tidak dapat dipisahkan juga dari pertimbangan situasi dan kondisi yang menuntut adanya perubahan sistem. Sebab masyarakat telah teradaptasi dengan dunia informasi dan digital, kemudian keberadaan lembaga pendidikan formal yang memerlukan pelimpahan wewenang, tanggung jawab serta kepercayaan bahwa bawahan memiliki potensi mengemban tugas, di samping gaya demokratis tidak mengurangi kharisma Kiai. Justru akan leih terbuka dan inklusif, artinya bawahan (pengurus) dapat memberikan usulan dan pemikiran kepada Kiai sehingga kebijakan pesantren akan cenderung partisipatif dengan mendengar pendapat arus bawah. ${ }^{64}$ Tidak hanya itu, menurut pandangan peneliti meminjam pendapat Sutarto dalam Syarif, bahwa sikap demokratis kepemimpinan Kiai dapat menyebabkan wewenang pimpinan menjadi tidak mutlak. Artinya, keputusan dan kebijaksanaan dapat dibuat bersama dengan bawahan sehingga komunikasi antar Kiai dengan pembantunya menjadi dua arah dan membuka kran ide dan pemikiran yang bersifat bottom-up. Namun pesantren tetap membuka pintu saran dan kritik demi sebuah kemajuan lembaga. Dengan demikian, tanggung jawab sebuah keberhasilan dapat dipikul secara bersama. ${ }^{65}$ Situasi ideal ini dalam pandangan peneliti telah diakomodir secara baik dalam implemetasi kepemimpinan demokratis versi TMI Al-Amien Prenduan.

\section{E. Kesimpulan}

Berdasarkan deskripsi pada bagian sebelumnya, penulis menyimpulkan bahwa otonomi yang diberikan pemerintah kepada pesantren mu'ādalah untuk melaksanakan bentuk pendidikan sesuai dengan local wisdom pesantren, telah melahirkan nilai-nilai kesetaraan yang menjadi konsep dan praksis pendidikan di lembaga tersebut. Sehingga istilah mu'ādalah tidak hanya setara secara lembaga, namun juga setara dalam substansi pendidikan. Beberaoa nilai kesetaraan dalam pendidikan Pesantren Mu'dalah Tarbiyah al-Muallimien Al-Islamiyah (TMI) Pesantren Al-Amien Prenduan Sumenep, di antaranya: Pertama, Nilai spiritual, yaitu Pancajiwa sebagai cahaya yang memancarkan jiwa Keikhlasan, jiwa kesederhanaan, jiwa kesanggupan menolong diri sendiri, berdikari (berdiri di atas kaki sendiri), jiwa ukhuwah Islamiyah yang demokratis antar santri dan Jiwa bebas. Kedua, keislaman dan keindonesiaan, yaitu nilai ketuhanan, nilai persatuan, nilai kebijkasanaan dalam kepemimpinan, nilai sosial keadilan. Ketiga, Integrasi nilai dan budaya sosial berdasarkan local culture pesantren, yaitu nilai kesetaraan

\footnotetext{
${ }^{63}$ Tentang sikap kehati-hatian Kyai dalam menerima modernitas baca Azyumardi Azra, Pendidikan Islam : Tradisi dan Modernisasi Menuju Millennium Baru, 101.

${ }^{64}$ Zainuddin Syarif, Dinamisasi Menejemen Pesantren, dari Tradisional Menuju Modern (Yogyakarta: Suka Press, 2007), 125.

${ }^{65}$ Zainuddin Syarif, Dinamisasi Menejemen Pesantren, 126; baca juga Sutarto, Dasar-dasar Kepemimpinan Administrasi (Yogyakarta: Gajah mada University Press, 1991), 75-76.
} 
Mufiqur Rahman, et. al.

dalam budaya pengabdian; nilai kesetaraan dalam budaya kaderisasi; nilai kesetaraan dalam budaya demokrasi dan penegakan disiplin. Beberapa nilai kesetaraan yang ada dalam pesantren mu'ādalah TMI Pesantren Al-Amien patut dipertahankan dan dijadikan sebagai role model bagi konsep dan praktik pendidikan saat ini. Namun demikian, nilai-nilai kesetaraan tersebut akan lebih berkembang apabila pesantren juga adaptif terhadap perkembangan zaman.

\section{F. Referensi}

al-Ghazali, Abu Hamid. Kimya' al-Sa'adah, diterj.KH. A. Mustofa Bisri, Surabaya: Pustaka Progressif, 2002.

Anugrah Octavian, Wendy, Urgensi memahami dan mengimplementasikan nilainilai Pancasila dalam kehidupan sehari-hari sebagai Sebuah bangsa (Jurnal Bhinneka Tunggal Ika, volume 5, nomor 2, november 2018)

Azra, Azyumardi. Pendidikan Islam : Tradisi dan Modernisasi Menuju millennium baru Jakarta : Logos Wacana IImu, 2002

Azra, Ayzumardi, Islam in Southeast Asia: Tolerance and Radicalism. Melbourne: The University of Melbourne, 2005).

Bagus, Lorens Kamus Filsafat, Jakarta: Gramedia Pustaka Utama, 2005.

Bakri, Maskuri, Islam, Pendidikan Multikultural, dan budaya damai; Telaah kritis tentang Indahnya perbedaan dalam Negara bangsa. Malang; Lembaga penerbitan Unisma, 2014

Bank, James A. \& Cherry A. McGee Banks, Multicultural Education : Issues and Perspective. United state of America: Willey, 2010.

Barbara J, Tayor Bacon. Education's role in democracy; the power of pluralism, Etica \& Politica / Ethics \& Politics, XII, 2010, 1, 135.

Castellia, Luciana at all , International Conference on Education and Educational Psychology (ICEEPSY 2012)Equity in education: a general overview (Procedia - Social and Behavioral Sciences 69 ( 2012 )

Daradjad, Zakiyah, IImu Pendidikan Islam, Jakarta: Bumi Aksara, 1992

Daryanto , Adiministrasi pendidikan (Jakarta; PT Rineka Cipta,1998), 289

Haris, Abd. Pendidikan Karakter berbasis tauhid; sebuah pendekatan filosofis, Sidoarjo: Al-Afkar Press, 2012

Hamzah, Moh. Transformasi Pondok Pesantren Mu'ädalah: antara fakta historis dan tantangan masa depan (Jurnal Reflektika Volume 13, no 1 Januari-Juni 2018)

Hefni, Mohammad. Penerapan Total Institution Di Pondok Pesantren Al-Amien Prenduan Sumenep (KARSA, Vol. 20 No. 1 Tahun 2012)

Jame P, Spradley, Participant Observation, New York: Holt, Rinehalt and Winston, 1980

Langgulung, Hasan, Manusia dan Pendidikan, Jakarta: Al-Husna Zikro, 1992

Marimba, Ahmad, Pengantar Filsafat Pendidikan Islam. Bandung; Almaarif, 1962.

Mastuhu, Dinamika sistem pendidikan Pesantren (Jakarta : INIS, 1989). 39-40

Muchlis Solichin, Mohammad. Tazkiyah al-Nafs sebagai Ruh rekontruksi sistem pendidikan Islam (Tadris, Volume 4 Nomor 1 2009)

Parmudi, Mochammad. Islam dan Demokrasi Di Indonesia; Dalam Perspektif Pengembangan Pemikiran Politik Islam (Laporan Hasil Penelitian individual, Dipa 2014)

Muhammad Ichsan, Demokrasi dan Syura perfpektif Islam dan Barat. Substantia, Volume 16 Nomor 1, April 2014, 6

Muhammad Tholhah Hasan, Pendidikan Multikultural sebagai opsi deradikalisasi. Malang; Unismapress 2017

Mushthafa al-Maraghiy, Ahmad . Tafsir al-Maraghy, Jilid 7 (Beirut : dar al-Fikr, 1974)

Madjid, Nurcholis Bilik-bilik Pesantren (Jakarta: Dian Rakyat, 2010)

Nawawi, Saifurrahman, Nilai Pendidikan Sufistik KH Imam Zarkasyi (Yogyakarta Sukapress, 2018

Peradaban Melayu di Indonesia (Studi Pemikiran Munawir Sjadzali) Jurnal Intelektualita: Keislaman, Sosial, dan Sains Volume 7, Nomor 1, Juni 2018, 41 
Peraturan Menteri Agama Republik Indonesia Nomor 18 tahun 2014 tentang satuan pendidikan muadalah pada pondok pesantren

Rahman, Mufiqur Demokrasi dalam filsafat pendidikan barat dan Islam :kajian tentang nilai-nilai demokrasi dan implementasinya dalam konteks pendidikan Indonesia (Cendekia : Jurnal Studi Keislaman Volume 3 nomor 2 Desember 2017)

Sabaruddin, NIlai-nilai demokrasi dalam pendidikan di Pesantren : Studi kasus pesantren-pesantren di Yogyakarta (Yoyakarta: Disertasi UINSUKA, 2011), 345

Satrock, Jhon W, Psikologi Pendidikan, Jakarta Selatan : Salemba Humanika, 2014

Sekretariat Pesantren Al-Amien, Profil singkat Pondok Pesantren Al-Amien Prenduan, 25

Susanto, Edi, Revitalisasi nilai luhur Tradisi Lokal Madura (KARSA, Vol. XII No. 2 Oktober 2007)

Susanto, Edi, Spiritualisasi pendidikan agama Islam: Menuju keberagamaan inklusif pluralistik (tadrîs :volume 9 nomor 1 juni 2014)

Sutarto, Dasar-dasar kepemimpinan administrasi. Yogyakarta: Gajah mada University Press, 1991

Syarif, Zainuddin. Dinamisasi menejemen pesantren, dari tradisional menuju modern Yogyakarta: Suka Press, 2007

Syaudih Sukmadinata, Nana. Metodologi Penelitian Pendidikan Bandung : Remaja Rosdakarya, cet . 2, 2006

Tidjani, Mohammad. Membangun Madura, Jakarta : Taj Publishing, 2008

Toharuddin, Nilai-Nilai Keislaman dan Keindonesiaan dalam Membentuk Karakteristik

Wahed, Abdurrahman. Prospek pesantren sebagai lembaga pendidikan dalam Sonhaji Sholeh. Jakarta P3M, 1988

Zarkasyi, Imam \& Sahal, Abdullah Wasiat, Pesan, dan harapan Pendiri Pondok Modern, Gontor:tth

Ziemek, Manfred. Pesantren dalam perubahan sosial. P3M Penghimpunan Pengembangan Pesantren dan Masyarakat, 1985

Wahid, Abdurrahman Pesantren sebagai subkultur, dalam M. Dawam Raharjo (Ed) Pesantren dan pembaharuan (Jakarta: LP3ES, 1974)

\section{Data Lapangan}

Hamzah (Kepala Marhalah Aliyah TMI Al-Amien), Wawancara pada 15 Desember 2019

Warta Singkat (warkat) TMI Pesantren Al-Amien Prenduan 2018

Jakfar Shodiq, Wawancara 16 Januari 2019

Nazmi, Wawancara 16 Januari 2019. 
Mufiqur Rahman, et. al. 